\title{
THE ROLE THAT NATURE CONSERVATION CAN PLAY TO MITIGATE THE SPREAD OF FUTURE INFECTIOUS DISEASES
}

\author{
Mattia Tonelli1 ${ }^{1,4}$, Jorge M. Lobo ${ }^{2}$, Yanina Benedetti ${ }^{3}$, Federico Morelli ${ }^{3}$, José R. Verdú ${ }^{4}$ \\ ${ }^{1}$ Department of Biomolecular Sciences (DISB), University of Urbino "Carlo Bo", 61029 Urbino, \\ PU, Italy. Mattia Tonelli ORCID: 0000-0003-3068-0492 \\ ${ }^{2}$ Dpto. Biogeografía y Cambio Global, Museo Nacional de Ciencias Naturales, (C.S.I.C), C/ José \\ Gutiérrez Abascal 2, 28006 Madrid, Spain. Jorge M. Lobo ORCID: 0000-0002-3152-4769 \\ ${ }^{3}$ Czech University of Life Sciences Prague, Faculty of Environmental Sciences, Community \\ Ecology \& Conservation, Kamýcká 129, CZ-165 00 Prague 6, Czech Republic. \\ Yanina Benedetti ORCID: 0000-0003-1600-2310 \\ Federico Morelli ORCID: 0000-0003-1099-1357 \\ ${ }^{4}$ I.U.I CIBIO (Centro Iberoamericano de la Biodiversidad), Universidad de Alicante, San Vi- \\ cente del Raspeig, 03690 Alicante, Spain. José R. Verdú ORCID: 0000-0002-0805-8341 \\ Corresponding author: Mattia Tonelli: mattia.tonelli@uniurb.it
}

\begin{abstract}
.
The emergence of infectious diseases is reviewed highlighting the potential role played by main environmental anthropogenic disturbances as, deforestation, land-use change, human-induced climate change, biodiversity loss and the illegal wildlife trade. Ultimately, it is plausible that the human impact on the biosphere could be the root cause of these emerging diseases, and that economic globalization, population growth and landscape anthropization might increase the likelihood of the emergence of novel zoonoses. This pattern bears similarities to phenomena that occurred during the Neolithic period with the emergence of agriculture and cattle domestication. Still today such phenomena could be accelerated by the vastly increased traffic of people and goods. Finally, we argue in favour of strong policies and actions aiming to mitigate the human impact on natural ecosystems as a key strategy to prevent future zoonoses.
\end{abstract}

Key words: biodiversity loss, climate change, coronavirus, deforestation, wildlife trading, zoonosis

\section{INTRODUCTION}

In December 2019, an unusual pneumonia outbreak was reported in Wuhan, Hubei province, China (Zhou et al. 2020; Wu et al. 2020). The cause of the illness, called Coronavirus Disease 19 (COVID-19), was traced to the virus denominated SARS-CoV-2 (Gorbalenya et al. 2020). At this time (April 2021), about fifteen months after the first case was discovered, SARS-CoV-2 has infected nearly 150 million people in 192 countries, causing more than 3,000,000 deaths (Dong et al. 2020). There is a broad consensus among the scientific community that SARS-CoV-2 has a zoonotic origin, but at the date no animal intermediate host has been identified (Andersen et al. 2020), although some studies suggest that bats of the genus Rhinolophus would be acting as natural reservoir and the Malaysian pangolin (Manis javanica, Desmarest, 1822) as intermediate host (Lam et al. 2020; Zhou et al. 2020). This lack of knowledge about the necessary intermediate host did not rule out the possibility that appearance of SARS-CoV-2 could be produced by the process of virus growth un- der laboratory iterations (serial passage; see Sirotkin \& Sirotkin 2020).

With its particular genetic and antigenic diversity that makes therapeutic solutions elusive, coronaviruses pose specific challenges (Sheahan \& Frieman 2020), but COVID-19 is only the latest of a growing number of emerging infectious diseases of zoonotic origins that affect humans. Zoonotic diseases are responsible for about 2.5 billion cases of infection and 2.7 million deaths every year, with substantial socioeconomic consequences (Gebreyes et al. 2014). Most of the infectious organisms that are pathogenic to humans (e.g. viruses, prions, bacteria, fungi, protozoa and helminths) have zoonotic origins (Jones et al. 2008; Taylor et al. 2001), including, Ebola, SARS, MERS, Hantavirus, HIV, Nipah virus, West Nile virus, Lyme disease and Rift Valley fever. Of all the parasite species listed as pathogenic to humans, at least $60 \%$ are zoonotic in origin (Taylor et al. 2001). However, apart from their crucial role in human disease, bacteria and viruses are intimately linked to the origin and functioning of life. Indeed, Earth may be 
home to upwards of one trillion microbial species (Locey \& Lennon 2016), viral genes outnumber cellular genes in the biosphere (Forterre \& Prangishvili 2013), and gene transfers from bacteria and viruses may be essential to shaping multicellular organisms (Callier 2019) and vertebrate immune systems (Broecker \& Moelling 2019). Hence, when we look at bacteria and viruses, we are looking at the most ancient and strongest evolutionary forces of genome dissemination in the history of life on Earth. Zoonotic diseases are thus part of human history and evolution, especially following the rise of agriculture and animal domestication and the passage from hunter/gatherer societies to sedentary or pastoralist settlements (Dobson \& Carper 1996; Düx et al. 2020; Wolfe et al. 2007). Even if we do not know what was the disease emergence rates before the Anthropocene, in the last decades, as a consequence of the Homogenocene epoch (sensu Samways 1999) with its unprecedented globalization of human actions, zoonotic infections seem to increase (Jones et al. 2008; Morand et al. 2014).

The precise emergence of a disease is impossible to predict since several factors could be involved in its appearance (Plowright et al. 2017), but it is recognized that one of the most critical causal factors is in the anthropogenic impacts on natural ecosystems and the altered human behaviours (Morse 1995; McMichael 2004; Jones et al. 2008; Jones et al. 2013; Allen

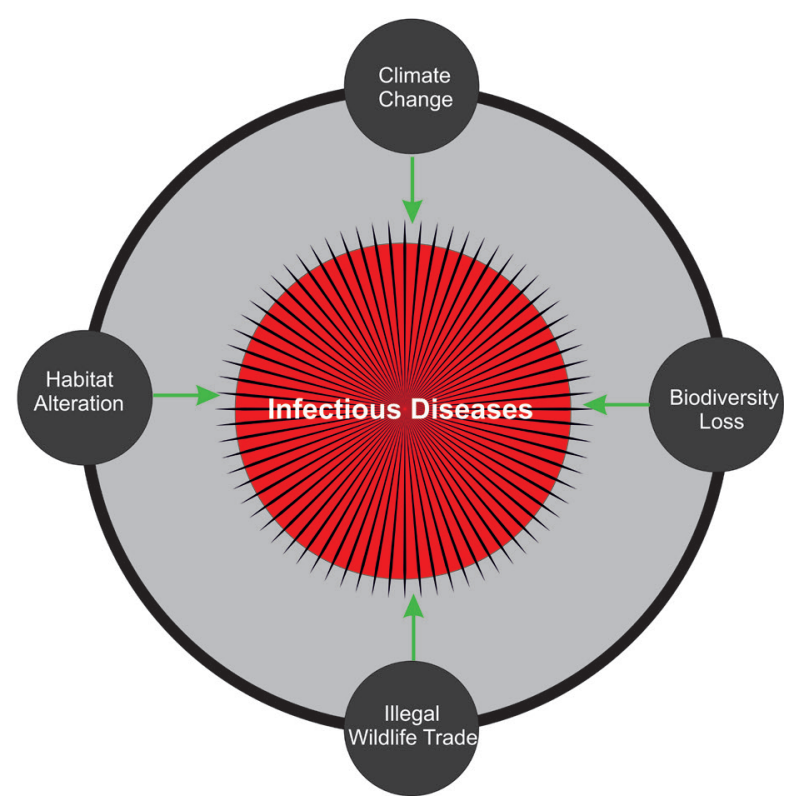

Figure 1. Relationship between four interconnected factors that impact emerging or re-emerging infectious diseases. et al. 2017). It is acknowledged that many current emerging infectious diseases, such as those related to coronaviruses, are associated with anthropogenic modifications of the environment (Pearce-Duvet 2006; Afelt et al._2018). These changes in the environment increase the likelihood of contact between wild fauna and humans and their livestock, thus increasing the risk of cross-species infection (Patz et al. 2004). Anthropogenic land use can influence disease transmission by altering vector niches, hosts, and pathogens; by changing community structures (e.g., species diversity or species composition) and the behaviour of hosts and vectors or by increasing direct contact between humans and wildlife reservoirs (Gottdenker et al. 2014). Therefore, analysing infectious diseases in the light of ecological and evolutionary theories is of great importance for understanding mechanisms, patterns, and effects of host-pathogen interactions and the role played by environmental factors (Jankowiak et al. 2020; Skórka et al. 2020).

Clearly, anthropogenic factors are not mutually exclusive, and their interaction can be complex, with positive, negative or neutral effects on disease emergence (Wood \& Lafferty 2013). However, several empirical studies point to a direct link between anthropogenic changes and emerging or re-emerging diseases. In particular, these investigations focus on four main interconnected factors, which ultimately can be viewed as different facets of a single whole: deforestation and changes in land-use, human-induced climate change, biodiversity loss and the illegal wildlife trade.

\section{Deforestation and Changes in Land-Use}

It has been estimated that $75 \%$ of zoonotic diseases are linked to wildlife (Taylor et al. 2001). Every year, millions of hectares of forest are permanently converted for agriculture, mining or energy infrastructure (Achard et al. 2002; Curtis et al. 2018). Hence, it is not surprising that the majority of emerging infectious diseases arise in forested tropical regions which generally have a high level of mammal diversity and thus can act as disease reservoirs. Indeed, greater host richness increases the pool from which novel pathogens may emerge (Allen et al. 2017; Murray \& Daszak 2013); hence, about 15\% of all emerging infectious diseases have a direct link to forests (Wilcox \& Ellis 2006). Deforestation can alter reservoir species or vector ecology (McMahon et al. 2018; Faust et al. 2018). When human settle- 
ments and activities (i.e. agriculture and livestock production) are located on the edge of the forest, anthropized landscapes can attract animals such as bats, rodent and passerine bird recognized as zoonotic hosts (Despommier et al. 2007; Jones et al. 2013; Kettle \& Koh 2014; Gibb et al. 2020). Therefore, the possibility of spatial overlap with pathogen viruses and the risk of spillover can increase significantly (Faust et al. 2018). Although forest habitat alteration and consequent changes in land-use appear to be a necessary but not sufficient factor in contributing to an increased risk of spillover (Hosseini et al. 2017), several examples underscore the role that deforestation can play in exacerbating the threat of spillover.

The Nipah virus is a paramyxovirus whose natural reservoir host is the Pteropus spp. fruit bat (Hyatt et al. 2004). The Nipah virus causes encephalitis and respiratory illness and has a mortality rate of about 39\% (Chua et al. 2000). It emerged in 1998 in Malaysia, and its emergence is likely related to the intensification of pig farming on the edge of tropical forests where fruit bats live. Deforestation affected the fruit bat population dynamics, and the bats were attracted to the fruit trees planted around the pig farms, infecting the pigs that consumed the fruit contaminated with bat saliva and urine. The pigs, in turn, acted as an amplifier host infecting humans (Daszak et al. 2006). Malaria also shows a strong link with deforestation. In Brazil, a 10\% rise in deforestation led to a $3.3 \%$ increase in malaria incidence due to the ecological alteration of Nyssorhynchus (Anopheles) darlingi (Root, 1926) habitats and breeding site availability (MacDonald \& Mordecai 2019; Vittor et al. 2009). Ebola provides another example of how deforestation can have an impact on emerging diseases. The Ebola virus was first identified in Africa in 1976 when it caused about 13,000 deaths, with a fatality rate of about 50\% (World Health Organization 2020). At that time, the natural reservoir of the Ebola virus appeared to be fruit bats with apes and monkeys acting as intermediate hosts (Leroy et al. 2005; De Nys et al. 2018; Ayouba et al. 2019). Although the use of bushmeat seems to be the primary direct mechanism in Ebola spillover (Alexander et al. 2015), deforestation also plays an important role in today's epidemics. Deforestation, indeed, can alter the virus ecology by changing the composition, abundance and behaviour of reservoir species, increasing the interface between human and animal populations and thus increasing the likelihood of exposure (Olivero et al. 2017,
2020; Rulli et al. 2017). Another essential change in land use that can act as an infectious disease driver is dam building. Although dam construction aims to increase food security and energy supplies, dams may lead to an increase in the incidence of numerous diseases, especially vector-borne illnesses, which are closely linked to wetlands. Indeed, dam projects have been shown to cause an increased incidence of multiple diseases, namely schistosomiasis, malaria, Rift Valley fever, filariasis, leishmaniasis, dracunculiasis, onchocerciasis and Japanese encephalitis (Myers et al. 2013). In the case of coronaviruses, environmental change has long been recognized as the main risk factor that can lead to new human infections. Indeed, the emergence of recent coronavirus outbreaks in Southeast Asia probably came in the wake of accelerated deforestation and land-use change in the region (Allen et al. 2017; Afelt et al. 2018). Finally, pandemic could be an indirect driver of tropical deforestation as proposed by Brancalion et al. (2020). Indeed, even if the causal linkage has to be confirmed, during COVID-19 pandemic and confinement measures, illegal and opportunistic forest clearing in tropical countries doubled compared to 2019 , showing that zoonotic diseases and deforestation could be linked by feedback loops with complex consequences (Brancalion et al. 2020).

\section{Chimate Change Associated with Human ACTIVITIES}

Human activities are the primary drives of global climate change leading to warmer temperatures, increased extreme weather events, the loss of ice and permafrost and changes in the biogeochemical cycles (IPCC 2013). Climate change has a substantial impact on faunal assemblages, their structure and the dispersion of their elements, which in turn can lead to infectious disease outbreaks. Such outbreaks are more likely to occur due to the altered ecophysiology of the host-pathogen interaction as well as the expanded ranges and modified population dynamics of the host (Altizer et al. 2013; Hoberg \& Brooks 2015). Using mammal-virus relationships and projections of geographic ranges Carlson et al. (2020) estimate that climate change may lead to alarming population aggregations, which could increase the share of viruses and the risk of exposure to pathogens. An example of how climate change affect disease emergence can be found in the Sin Nombre Virus (SNV), a Hantavirus which causes a severe disease called Hantavirus Car- 
diopulmonary Syndrome (HCPS) with a mortality rate of about 35\% (Richardson et al. 2013). A natural reservoir of SNV is the deer mouse Peromyscus maniculatus (Wagner, 1845), which excretes virus in its urine, faeces and saliva (Childs et al. 1994). El Niño events in 1991-92 and 1997-98 increased the incidence of human infections in the Southwestern USA through an ecological cascade effect. Briefly, increased precipitation resulted in greater trophic and habitat availability for rodents, whose population density grew, producing more frequent virus transmission and host dispersal. These events were followed by a three-year increase in the number of HCPS cases in the Southwestern United States (Klempa 2009; Carver et al. 2015; Dearing \& Dizney 2010; Mills et al. 2010). Another disease that is driven by climate is meningococcal meningitis, found in parts of Africa. This infection of the meninges is caused by the bacterium Neisseria meningitides (Albrecht \& Ghon 1901) Murray, 1929, which, in the so-called African meningitis belt (sub-Saharan Africa, from Senegal to Ethiopia), causes between 7,000 to 180,000 cases annually with a mortality rate ranging between $10 \%$ and $20 \%$ (Borrow et al. 2017). The bacterium is highly contagious and is transmitted from person to person through the air via respiratory secretions. The climate has a significant effect on this disease. Indeed, upsurges in outbreaks of the disease are reported during the dry season, when hot dry air and dust may create the conditions for disease transmission by damaging the mucosal barrier and inhibiting its immune capacity (Sultan et al. 2005; García-Pando et al. 2014). Another very relevant case is dengue, one of the most important arboviral diseases in the world with an incidence that has increased 30 fold in the last 50 years (e.g. 390 million infections in 2010). Among other factors related to globalization, global warming is the most crucial driver of the current distribution and incidence of the primary dengue vectors Aedes aegypti (L. 1762) and A. albopictus Skuse, 1895 (Ebi \& Nealon 2016). Although there is not a broad consensus on the effect of climate change on disease vectors, due to the complex and nonlinear relationships of the variables involved (Franklinos et al. 2019), climate change may drive arthropod-borne diseases (Patz et al. 1996, 2005). In particular, it could do so by spreading vectors in temperate and high altitude zones, bringing together organisms that were previously separated, and increasing the incidence of arthropod-borne diseases by modifying vector devel- opment, survival, biting rates, and population density (Ogden \& Lindsay 2016; Caminade et al. 2019).

\section{BIODIVERSITY LOSS}

The current rate of species extinction is about 1000 times the natural background rate (Pimm et al. 2014), and biodiversity loss can increase the risk of pathogen spillover, especially for vector-borne diseases (Pongsiri et al. 2009; Civitello et al. 2015). Generally, vectors feed on a broad range of hosts, some of which are not very pathogen competent. Hence, in highly diverse communities, a reduction in the encounter rate between vectors and the most competent hosts may reduce the risk of disease due to a "dilution effect" (Keesing et al. 2006). On the contrary, a loss of biodiversity could increase the risk of disease due to the increased likelihood of encounters with competent hosts (Keesing et al. 2010; Jones et al. 2013). An example of increased pathogen transmission and disease incidence due to biodiversity loss can be found in the case of the West Nile virus. The West Nile virus is a mosquito-borne disease that can cause severe neurological illness in humans (Petersen et al. 2013). The natural reservoirs for the West Nile virus are birds, and passerines tend to be the most competent hosts compared to non-passerine birds (Komar et al. 2003). Several studies have found that a loss of avian biodiversity (especially non-passerine birds) is related to an increased incidence of West Nile virus in humans in the United States (Allan et al. 2009; Ezenwa et al. 2006; Swaddle \& Calos 2008), corroborating the dilution effect hypothesis. Another example of increased human disease risk due to biodiversity loss regards Lyme disease, caused by a spirochete bacterium transmitted by feeding ticks of the genus Ixodes. If untreated, Lyme disease can cause arthritis as well as neurological and cardiac symptoms, which can persist for years even after treatments (Franz \& Krause 2003). Ticks are ecologically generalist species and feed on several species of vertebrates, but the white-footed mouse (Peromyscus leucopus (Rafinesque, 1818)) seems to be the most competent reservoir for the pathogen in eastern North America (Schmidt \& Ostfeld 2001). It has been shown that a loss of diversity among vertebrates that are poor reservoirs for the Lyme spirochete could increase tick infection and, consequently, the incidence of Lyme disease due to a loss of dilution hosts (Schmidt \& Ostfeld 2001; Ostfeld \& Keesing 2000; LoGiudice et al. 2003). Moreover, not only is the 
number of species essential for diminishing disease risk, but also the identity of the species could have an important effect on emerging diseases. For example, the loss of predator species may increase disease risk more than the loss of other species (Ostfeld \& Holt 2004; Rohr et al. 2015). An example of this ecological process is found in the case of Schistosomiasis in Lake Malawi. Schistosomiasis is a parasitic disease caused by trematodes of the genus Schistoso$m a$, affecting over 250 million people in 78 countries around the world and causing about 280,000 deaths each year (LoVerde 2019). Schistosomes require specific freshwater snail species to complete their life cycles, and people are infected when they enter in contact with water containing trematode cercariae (the infective larval stage). In Lake Malawi, overfishing caused a decrease in the Cichlid Trematocranus placodon (Regan, 1922), a snail predator, leading to an increase in the snail population, which in turn led a rise in schistosome parasite transmission to humans (Evers et al. 2006; Stauffer et al. 2006). Finally, it was demonstrated that, at a global scale, anthropogenic habitat disturbance has a differential effect on biodiversity composition. Indeed, land-use change increases the abundance and the richness of wildlife hosts of human-shared pathogens and parasites in anthropized areas, which reflect a potential zoonotic hazard (Gibb et al. 2020). Hence, it seems that synanthropic species (e.g. bats, rodents or passerine birds), which increase in diversity as a result of anthropogenic disturbances, are more likely to be pathogenic hosts capable to harbouring a greater number of pathogen species, including those infectious for humans (Beyer et al. 2021; Gibb et al. 2020; Johnson et al. 2020; Ostfeld \& Keesing, 2020).

\section{The Illegal Animal Trade and Bushmeat}

The wildlife trade and consumption of bushmeat are already well recognized as a threat to the global conservation of nature (Scheffers et al. 2019). Besides, wildlife trade can increase a direct contact between wildlife and humans, increasing the risk of disease emergence. Dozens of pathogens have been isolated in illegally traded wildlife species (Gómez \& Aguirre 2008) with a high risk of spillover and disease spread in new areas (Pavlin et al. 2009). The illegal wildlife trade is one of the largest black markets in the world, second only to drug trafficking (Toledo et al. 2012). From 1998 to 2007 around 30 million animals from 300 CITES-listed species were exported worldwide from Southeast Asia (Nijman 2009), and it is estimated that the same order of magnitude of individuals and species is sold each year in the wet markets of East and Southeast Asia (Karesh et al. 2005). As reported by Karesh et al. (2005), "these numbers combined suggest that at least some multiple of 1 billion direct and indirect contacts among wildlife, humans, and domestic animals result from the wildlife trade annually". In several rural areas of the world, bushmeat consumption has played a relevant role for several generations, providing an essential source of protein in people's diets and supporting local economies (Milner-Gulland et al. 2003). Nevertheless, deforestation and the construction of new roads, as well as the expansion of luxury markets for bushmeat in "developed" countries (Chaber et al. 2010) have made this practice not only detrimental to the conservation of biodiversity (Milner-Gulland et al. 2003), but also a growing threat to global health because of its potential to facilitate the spread of emerging infectious diseases (Swift et al. 2007). An example of how the illegal wildlife trade can cause the emergence and spread of disease is the 2003 monkeypox outbreak in the United States, which led to dozens of human infections (Reed et al. 2004; Di Giulio \& Eckburg 2004). The virus was introduced through the importation of several African rodents, which were kept with other mammals, including prairie dogs (Bernard $\&$ Anderson 2006). Another example can be found in the 2002 outbreak of Severe Acute Respiratory Syndrome (SARS) caused by the virus SARS-CoV. The virus emerged in Guongdong province (China), with 8422 confirmed cases, 916 deaths and a mortality rate of about 11\% (Chan-Yeung \& Xu 2003). Although bats of the genus Rhinolophus appear to be the natural reservoir of SARS-CoV, the masked palm civet (Paguma larvata (C.E.H. Smith, 1827)) probably acted as an intermediate host transmitting the virus to humans at live animal markets ( $\mathrm{Li}$ et al. 2005; Hu et al. 2017). Finally, the most important virus that traces its origins to bushmeat hunting and consumption is the Human Immunodeficiency Virus (HIV), which causes the Acquired Immune Deficiency Syndrome (AIDS). Over the last four decades, about 60 million people have been infected with HIV, and about 25 million people have died of AIDS (Merson et al. 2008). The virus evolved from the simian immunodeficiency virus (SIV), and there are several pieces of evidence indicating that primate hunting, butchering, and consumption were the principal drivers of HIV emergence (Peeters et al. 2002; Sharp \& Hahn 2011). 


\section{Conclusions}

All the examples cited above point to the probable relationship between the increasing human impact on natural environments and emerging and re-emerging diseases. The human population has increased from 4.4 million people in the early Holocene period to around 7,800 million todays. Before the industrial revolution, approximately 600 million people populated the Earth and this figure has grown exponentially over the last 300 years registering a 13-fold increase (Goldewijk et al. 2017) linked to the use of high energy fossil fuel. The increase in the land used for grazing and crops has followed similar trends. While $7.3 \%$ of the Earth land area was destined for anthropic uses in 1700, the current percentage is close to $37.1 \%$ (Goldewijk et al. 2017), taking a heavy toll on the "natural" environment. The consequences of this increase are many, affecting the structure and functioning of the entire Earth system: the concentrations of carbon dioxide and methane and have risen to the point that they are now driving climate change. Many researchers now consider that Earth is presently in its sixth great extinction event (Ceballos et al. 2017) and different environmental problems accumulate (Ripple et al. 2020); fertilizer production from atmospheric nitrogen and fossil fuels exceeds that which is generated by natural processes, human appropriation of the net primary production of potential vegetation is about $25 \%$, and the human contribution to the global production of sediments is more than 24 times higher than the sediments supplied by world's rivers (Steffen et al. 2007; Krausmann et al. 2013; Cooper et al. 2018).

We are aware that the listed factors are not the only one involved in a zoonotic spillover (Plowright et al. 2017) and there are a context and scale dependency (Hosseini et al. 2017). Indeed, no pandemic has ever been predicted, and more research is needed to understand in deep the factors and the interactions that drive the emergence of zoonosis (Morse et al. 2012). However, the human impact on the biosphere can be counted among the key causes of emerging and re-emerging diseases (Plowright et al. 2008; Morse 1995). It would appear that increased contact between humans and other organisms is a decisive factor, even if not sufficient, in the emergence of pandemics, and the connections facilitating zoonoses could grow with economic globalization, population growth and landscape anthropization. This process is similar to the process related to the emergence of agriculture and cattle domestication during the Neolithic period (Wolfe et al. 2007), but now could be accelerated by the exponentially increased traffic in people and goods. Ecology and cybernetics have shown us that large networks with many interactions between their components are frequently unstable and fragile (Pasqualetti et al. 2020). Evolution continually fosters systems of relationships between living things that are compartmentalized and adapted to their local conditions. When human actions alter these local systems, globalizing and homogenizing them, the consequence is the invasion of foreign species, the loss of biological diversity and a breakdown in the functionality of ecosystems. It is revealing that the globalized economy, in its constant striving for ever higher productivity, blindly favours systems of relationships between living things which are the opposite of the kinds of relationships fostered by the evolution of natural systems. We know that most zoonoses originate from the domestication of and interaction with wild animals, and that more than 10,000 animal viruses can potentially be transmitted to humans (Carlson et al. 2019). This transmission could be accelerated by the increasing mobility of goods and people, but also by changes in the climate that lead to the dispersal of human and animal populations, as well as the continuous environmental degradation and loss of biodiversity that can facilitate our contact with pathogens. Insisting on a globalized economic strategy to the detriment of local production and consumption networks cannot be said to be a reasonable strategy to avoid future humanitarian and environmental disasters.

Even though anthropogenic impacts on ecosystems can be seen as one of the most important factors in the emergence of human infectious diseases, today scientific and economic efforts to reduce the impacts of pathogens are mainly focused on quarantine strategies and the development of new drugs and vaccines (Pike et al. 2014). In other words, our global strategy attempts to mitigate the impact after a disease has already emerged, but does not include preventive measures aiming to minimize the human impact on natural ecosystems. Every year, only $\$ 6$ billion is spent on the management of protected areas around the world (James et al. 2001), a sum which is several orders of magnitude lower than the economic loss caused by infectious diseases and post-emergence investment and costs (World Bank 2012; Pimentel et al. 2001; McKibbin \& Sidorenko 2006) 
such as the EU fund set up (https://global-response. europa.eu/index_en) to ensure universal deployment of diagnostics, treatment and vaccines against COVID-19. If we only take into consideration six major outbreaks of fatal zoonoses in the last few decades (Nipah Virus, West Nile Fever, SARS, HPAI, BSE, Rift Valley Fever), we could have saved an average of $\$ 6.7$ billion per year if these outbreaks had been prevented (World Bank 2012). Moreover, vaccine development for each of the principal epidemic infectious diseases could cost a minimum of \$2.8-3.7 billion (Gouglas et al. 2018). In 2003, the SARS outbreak alone caused a worldwide economic loss of about $\$ 40$ billion (Lee \& McKibbin 2004), the 2014 Ebola outbreak in West Africa caused an economic loss of more than $\$ 50$ billion (Huber et al. 2018), and to date, HIV/AIDS may have cost $\$ 500$ billion (Greger 2007). Recently, the Asian Development Bank (ADB), using the Global Trade Analysis Project model, estimates that the global economic impact of COVID-19 could reach $\$ 8.8$ trillion $(9.7 \%$ of global GDP) under a 6-month containment scenario (Park et al. 2020). These data underscore the global society's focus on post-emergence pathogen mitigation, and its inability to examine the root causes of the problem.

A shift from a reactive to a preventive strategy is urgently needed to avoid the emergence of future infectious diseases. Nature conservation must be adopted as a fundamental tool alongside health surveillance, medical treatments and vaccine research to avert future global health crises. Furthermore, infectious disease prevention strategies should be integrated into sustainable development plans (Di Marco et al. 2020). It is clear that nature conservation is not just an ethical problem; instead, it is a crucial issue that will determine the future safety of humankind (Costanza et al. 2014) as well as the human physical and psychological well-being (Balmford \& Bond 2005; Murawiec \& Tryjanowski 2020; Soga et al. 2020). To avert future global health crises politicians and governments around the world should seek to prioritize the conservation of nature and the implementation of green policies (Newell 2019).

\section{ACKNOWLEDGMENTS}

We wish to thank Timothy Clifford Bloom for his linguistic revision of the manuscript.

\section{FUNDING}

This research did not receive any specific grant from funding agencies in the public, commercial, or not-for-profit sectors.

\section{REFERENCES}

Achard, F., Eva, H.D., Stibig, H.-J., Mayaux, P., Gallego, J., Richards, T. \& Malingreau, J.-P. (2002) Determination of deforestation rates of the world's humid tropical forests. Science, 297, 999-1002. https://doi. org/10.1126/science. 1070656

Afelt, A., Frutos, R. \& Devaux, C. (2018) Bats, Coronaviruses, and deforestation: toward the emergence of novel infectious diseases? Frontiers in Microbiology, 9, 702. doi: 10.3389/fmicb.2018.00702

Alexander, K.A., Sanderson, C.E., Marathe, M., Lewis, B.L., Rivers, C.M., Shaman, J., et al. (2015) What factors might have led to the emergence of Ebola in West Africa? PLoS Neglected Tropical Diseases, 9(6), e0003652. https://doi.org/10.1371/journal. pntd.0003652

Allan, B.F., Langerhans, R.B., Ryberg, W.A., Landesman, W.J., Griffin, N.W., Katz, R.S., et al. (2009) Ecological correlates of risk and incidence of West Nile virus in the United States. Oecologia, 155, 699-708. https:// doi.org/10.1007/s00442-008-1169-9

Allen, T., Murray, K.A., Zambrana-Torrelio, C., Morse, S.S., Rondinini, C., Di Marco, M., et al. (2017) Global hotspots and correlates of emerging zoonotic diseases. Nature Communications, 8,1124 . https://doi. org/10.1038/s41467-017-00923-8

Altizer, S., Ostfeld, R.S., Johnson, P.T.J., Kutz, S., Harvell, C.D. (2013) Climate change and infectious diseases: from evidence to a predictive framework. Science, 341, 514-519. https://doi.org/10.1126/science. 1239401

Andersen, K.G., Rambaut, A., Lipkin, W.I., Holmes, E.C., Garry, R.F. (2020) The proximal origin of SARSCoV-2. Nature Medicine, 26, 450-452. https://doi. org/10.1038/s41591-020-0820-9

Ayouba, A., Ahuka-Mundeke, S., Butel, C., Kingebeni, P.M., Loul, S., Tagg, N., et al. (2019) Extensive serological survey of multiple African nonhuman primate species reveals low prevalence of immunoglobulin $\mathrm{G}$ antibodies to 4 Ebola virus species. The Journal of Infectious Diseases, 220, 1599-1608. https://doi. org/10.1093/infdis/jiz006

Balmford, A., Bond, W. (2005) Trends in the state of nature and their implications for human well-being. Ecology Letters, 8: 1218-1234. doi: 10.1111/j.14610248.2005.00814.x 
Bernard, S.M., Anderson, S.A. (2006) Qualitative assessment of risk for monkeypox associated with domestic trade in certain animal species, United States. Emerging Infectious Diseases, 12(12), 1827-1833. https:// dx.doi.org/10.3201/eid1212.060454

Beyer, R.M., Manica, A., Mora, C. (2021) Shifts in global bat diversity suggest a possible role of climate change in the emergence of SARS-CoV-1 and SARS-CoV-2. Science of the Total Environment, 767: 145413. https://doi.org/10.1016/j.scitotenv.2021.145413

Borrow, R., Caugant, D.A., Ceyhan, M., Christensen, H., Dinleyici, E.C., Findlow, J., et al. (2017) Meningococcal disease in the Middle East and Africa: Findings and updates from the Global Meningococcal Initiative. Journal of Infection, 75(1), 1-11. https://doi. org/10.1016/j.jinf.2017.04.007

Brancalion, P.H.S., Broadbent, E.N., de-Miguel, S., Cardil, A., Rosa, M.R., Almeida, C.T., et al. (2020) Emerging threats linking tropical deforestation and the COVID-19 pandemic. Perspectives in Ecology and Conservation, Online version, https://doi.org/10.1016/j. pecon.2020.09.006

Broecker, F., Moelling, K. (2019) Evolution of immune systems from viruses and transposable elements. Frontiers in Microbiology, 10, 51. https://doi.org/10.3389/ fmicb.2019.00051

Callier, V. (2019) Gene transfers from bacteria and viruses may be shaping complex organisms. Proceedings of the National Academy of Sciences, 116, 1371413716. https://doi.org/10.1073/pnas.1909030116

Caminade, C., McIntyre, K.M., Jones, A.E. (2019) Impact of recent and future climate change on vector-borne diseases. Annals of the New York Academy of Sciences, 1436, 157-173. https://doi.org/10.1111/nyas.13950

Carlson, C.J., Albery, G.F., Merow, C., Trisos, C.H., Zipfel, C.M., Eskew, E.A., et al. (2020) Climate change will drive novel cross-species viral transmission. bioRxiv, doi: https://doi.org/10.1101/2020.01.24.918755.

Carlson, C.J., Zipfel, C.M., Garnier, R., Bansal, S. (2019) Global estimates of mammalian viral density accounting for host sharing. Nature Ecology \& Evolution, 3, 1070-1075. https://doi.org/10.1038/s41559-0190910-6

Carver, S., Mills, J.N., Parmenter, C.A., Parmenter, R.R., Richardson, K.S., Harris, R.L., et al. (2015) Toward a mechanistic understanding of environmentally forced zoonotic disease emergence: Sin Nombre Hantavirus. Bioscience, 65(7), 651-666. https://doi.org/10.1093/ biosci/biv047

Ceballos, G., Ehrlich, P.R., Dirzo, R. (2017) Biological annihilation via the ongoing sixth mass extinction signaled by vertebrate population losses and declines. Proceedings of the National Academy of Sciences, 114, E6089-E6096. https://doi.org/10.1073/ pnas. 1704949114

Chaber, A.-L., Allebone-Webb, S., Lignereux, Y., Cunningham, A.A., Rowcliffe, J.M. (2010) The scale of illegal meat importation from Africa to Europe via Paris. Conservation Letters, 3, 317-323. https://doi. org/10.1111/j.1755-263X.2010.00121.x

Chan-Yeung, M., Xu, R.-H. (2003) SARS: epidemiology. Respirology, 8, S9-S14. https://doi.org/10.1046/ j.1440-1843.2003.00518.x

Childs, J.E., Ksiazek, T.G., Spiropoulou, C.F., Krebs, J.W., Morzunov, S., Maupin, G.O., et al. (1994) Serologic and genetic identification of Peromyscus maniculatus as the primary rodent reservoir for a new hantavirus in the southwestern United States. The Journal of Infectious Disease, 169, 1271-1280. https://doi. org/10.1093/infdis/169.6.1271

Chua, K.B., Bellini, W.J., Rota, P.A., Harcourt, B.H., Tamin, A., Lam, S.K., et al. (2000) Nipah virus: a recently emergent deadly paramyxovirus. Science, $288,1432-$ 1435. https://doi.org/10.1126/science.288.5470.1432

Civitello, D.J., Cohen, J., Fatima, H., Halstead, N.T., Liriano, J., McMahon, T.A., et al. (2015) Biodiversity inhibits parasites: Broad evidence for the dilution effect. Proceedings of the National Academy of Sciences, 112, 8667-8671. https://doi.org/10.1073/ pnas. 1506279112

Cooper, A.H., Brown, T.J., Price, S., Ford, J.R., Waters, C.N. (2018) Humans are the most significant geomorphological driving force of the 21 st century. The Anthropocene Review, 5, 222-229. https://doi. org/10.1177/2053019618800234

Costanza, R., de Groot, R., Sutton, P., van der Ploeg, S., Anderson, S.J., Kubiszewski, I., et al. (2014) Changes in the global value of ecosystem services. Global Environmental Change, 26, 152-158. https://doi. org/10.1016/j.gloenvcha.2014.04.002

Curtis, P.G., Slay, C.M., Harris, N.L., Tyukavina, A., Hansen, M.C. (2018) Classifying drivers of global forest loss. Science, 361, 1108-1111. https://doi. org/10.1126/science.aau3445

Daszak, P., Plowright, R.K., Epstein, J.H., Pulliam, J., Abdul Rahman, S., Field, H.E., et al. (2006) The emergence of Nipah and Hendra virus: pathogen dynamics across a wildlife-livestock-human continuum. In: Collinge, S.K. and Ray, C., (Eds.), Disease Ecology: Community structure and pathogen dynamics. Oxford University Press, Oxford, pp. 186-201. 
De Nys, H. M., Kingebeni, P., Keita, A. K., Butel, C., Thaurignac, G., Villabona-Arenas, C. J., et al. (2018) Survey of Ebola Viruses in Frugivorous and Insectivorous Bats in Guinea, Cameroon, and the Democratic Republic of the Congo, 2015-2017. Insectivorous Bats in Guinea, Cameroon, and the Democratic Republic of the Congo, 2015-2017. Emerging Infectious Diseases, 24(12), 2228-2240. https://dx.doi. org/10.3201/eid2412.180740.

Dearing, M.D., Dizney, L. (2010) Ecology of hantavirus in a changing world. Annals of the New York Academy of Sciences, 1195, 99-112. https://doi.org/10.1111/ j.1749-6632.2010.05452.x

Despommier, D., Ellis, B.R., Wilcox, B.A. (2007) The role of ecotones in emerging infectious diseases. EcoHealth, 3, 281-289. https://doi.org/10.1007/s10393006-0063-3

Di Giulio, D.B., Eckburg, P.B. (2004) Human monkeypox: an emerging zoonosis. Lancet Infectious Diseases, 4, 199. https://doi.org/10.1016/S1473-3099(03)00856-9

Di Marco, M., Baker, M.L., Daszak, P., De Barro, P., Eskew, E.A., Godde, C.M., et al. (2020) Sustainable development must account for pandemic risk. Proceedings of the National Academy of Sciences, 117, 3888-3892. https://doi.org/10.1073/pnas.2001655117

Dobson, A.P., Carper, E.R. (1996) Infectious diseases and human population history. BioScience, 46(2), 115126. https://doi.org/10.2307/1312814

Dong, E., Du, H., Gardner, L. (2020) An interactive webbased dashboard to track COVID-19 in real time. Lancet Infectious Diseases, published online Feb 19. https://doi.org/10.1016/S1473-3099(20)30120-1

Düx, A., Lequime, S., Patrono, L.V., Vrancken, B., Boral, S., Gogarten, J.F., et al. (2020) Measles virus and rinderpest virus divergence dated to the sixth century BCS. Science, 368, 1367-1370. https://doi. org/10.1126/science.aba9411

Ebi, K.L., Nealon, J. (2016) Dengue in a changing climate. Environmental Research, 151, 115-123. https://doi. org/10.1016/j.envres.2016.07.026

Evers, B.N., Madsen, H., McKaye, K.M., Stauffer, J.R. (2006) The schistosome intermediate host, Bulinus nyassanus, is a 'preferred' food for the cichlid fish, Trematocranus placodon, at Cape Maclear, Lake Malawi. Annals of Tropical Medicine and Parasitology, 100(1), 75-85. https://doi. org/10.1179/136485906X78553

Ezenwa, V.O., Godsey, M.S., King, R.J. Guptill, S.C. (2006) Avian diversity and West Nile virus: testing associations between biodiversity and infectious dis- ease risk. Proceedings of the Royal Society B, 273, 109-117. https://doi.org/10.1098/rspb.2005.3284

Faust, C.L., McCallum, H.I., Bloomfield, L.S.P., Gottdenker, N.L., Gillespie, T.R., Torney, C.J., et al. (2018) Pathogen spillover during land conversion. Ecology Letters, 21, 471-483. https://doi.org/10.1111/ ele. 12904

Forterre, P., Prangishvili, D. (2013) The major role of viruses in cellular evolution: facts and hypotheses. Current Opinion in Virology, 3(5), 558-565. https://doi. org/10.1016/j.coviro.2013.06.013

Franklinos, L.H.V., Jones, K.E., Redding, D.W., Abubakar, I. (2019) The effect of global change on mosquito-borne disease. Lancet Infectious Diseases, 19, E302-E312. https://doi.org/10.1016/S14733099(19)30161-6

Franz, J.K., Krause, A. (2003) Lyme disease (Lyme borreliosis). Best practice \& Research Clinical Rheumatology, 17(2), 241-264. https://doi.org/10.1016/S15216942(02)00129-8

García-Pando, C.P., Thomson, M.C., Stanton, M.C., Diggle, P.J., Hopson, T., Pandya, R., et al. (2014) Meningitis and climate: from science to practice. Earth Perspectives, 1, 14. https://doi.org/10.1186/21946434-1-14

Gebreyes, W.A., Dupouy-Camet, J., Newport, M.J., Oliveira, C.J.B., Schlesinger, L.S., Saif, Y.M., et al. (2014) The global one health paradigm: challenges and opportunities for tackling infectious diseases at the human, animal, and environment interface in low-resource settings. PLoS Neglected Tropical Diseases, 8(11), e3257. https://doi.org/10.1371/journal. pntd. 0003257

Gibb, R., Redding, D.W., Chin, K.Q., Donnelly, C.A., Blackburn, T.M., Newbold, T., Jones, K.E. (2020) Zoonotic host diversity increases in human-dominated ecosystems. Nature, 584, 398-402. https://doi. org/10.1038/s41586-020-2562-8

Goldewijk, K.K., Beusen, A., Doelman, J., Stehfest, E. (2017) Anthropogenic land use estimates for the Holocene- HYDE 3.2. Earth System Science Data, 9, 927-953. https://doi.org/10.5194/essd-9-927-2017

Gómez, A., Aguirre, A.A. (2008) Infectious diseases and the illegal wildlife trade. Annals of the New York Academy of Sciences, 1149, 16-19. https://doi. org/10.1196/annals. 1428.046

Gorbalenya, A.E., Baker, S.C., Baric, R.S., de Groot, R.J., Drosten, C., Gulyaeva, A.A., et al. (2020) The species Severe acute respiratory syndrome-related coronavirus: classifying 2019-nCoV and naming it SARS- 
CoV-2. Nature Microbiology, 5, 536-544. https://doi. org/10.1038/s41564-020-0695-z

Gottdenker, N.L., Streicker, D.G., Faust, C.L., Carroll, C.R. (2014) Anthropogenic land use change and infectious diseases: a review of the evidence. EcoHealth, 11, 619-632. https://doi.org/10.1007/s10393014-0941-z

Gouglas, D., Le, T.T., Henderson, K., Kaloudis, A., Danielsen, T., Hammersland, N.C., et al. (2018) Estimating the cost of vaccine development against epidemic infectious diseases: a cost minimization study. Lancet Global Health, 6, e1386-e1396. https://doi. org/10.1016/S2214-109X(18)30346-2

Greger, M. (2007) The human/animal interface: emergence and resurgence of zoonotic infectious diseases. Critical Reviews in Microbiology, 33(4), 243-299. https://doi.org/10.1080/10408410701647594

Hoberg, E.P., Brooks, D.R. (2015) Evolution in action: climate change, biodiversity dynamics and emerging infectious disease. Philosophical Transactions of the Royal Society B, 370, 20130553. https://doi. org/10.1098/rstb.2013.0553

Hosseini, P.R., Mills, J.N., Prieur-Richard, A.-H., Ozenwa, V.O., Bailly, X., Rizzoli, A., et al. (2017) Does the impact of biodiversity differ between emerging and endemic pathogens? The need to separate the concept of hazard and risk. Philosophical Transactions of the Royal Society B, 372, 20160129. https://doi. org/10.1098/rstb.2016.0129

Hu, B., Zeng, L.-P., Yang, X.-L., Ge, X.-Y., Zhang, W., Li, B., et al. (2017) Discovery of a rich gene pool of bat SARS-related coronaviruses provides new insights into the origin of SARS coronavirus. PLoS Pathogens, 13(11), e1006698. https://doi.org/10.1371/journal.ppat. 1006698

Huber, C., Finelli, L., Stevens, W. (2018) The economic and social burden of the 2014 Ebola outbreak in West Africa. The Journal of Infectious Diseases, 218, S698-S704. https://doi.org/10.1093/infdis/jiy213

Hyatt, A.D., Daszak, P., Cunningham, A.A., Field, H., Gould, A.R. (2004) Henipaviruses: gaps in the knowledge of emergence. EcoHealth, 1, 25-38. https://doi. org/10.1007/s10393-004-0017-6

IPCC (2013) Climate change 2013: the physical science basis. Contribution of working group I to the fifth assessment report of the intergovernmental panel on climate change [Stocker, T.F., Qin, D., Plattner, G.K., Tignor, M., Allen, S.K., Boschung, J., Nauels, A., Xia, Y., Bex, V., Midgley, P.M., (eds)]. Cambridge University Press, Cambridge, United Kingdom and New York, NY, USA, 1535 pp.
James, A., Gaston, K.J., Balmford, A. (2001) Can we afford to conserve biodiversity? BioScience, 51(1), 4352. https://doi.org/10.1641/0006-3568(2001)051[004 3:CWATCB]2.0.CO;2

Jankowiak, Ł., Rozsa, L., Tryjanowski, P., Møller, A.P. (2020) A negative covariation between toxoplasmosis and COVID-19 with alternative interpretations. Scientific Reports, 10: 12512. https://doi.org/10.1038/ s41598-020-69351-x

Johnson, C.K., Hitchens, P.L., Pandit, P.S., Rushmore, J., Evans, T.S., Young, C.C.W., Doyle, M.M. (2020) Global shifts in mammalian population trends reveal key predictors of virus spillover risk. Proceedings of the Royal Society B, 287: 20192736. http://dx.doi. org/10.1098/rspb.2019.2736

Jones, B.A., Grace, D., Kock, R., Alonso, S., Rushton, J., Said, M.Y., et al. (2013) Zoonosis emergence linked to agricultural intensification and environmental change. Proceedings of the National Academy of Sciences, 110, 8399-8404. https://doi.org/10.1073/ pnas. 1208059110

Jones, K.E., Patel, N.G., Levy, M.A., Storeygard, A., Balk, D., Gittleman, J.L., Daszak, P. (2008) Global trends in emerging infectious diseases. Nature, 451, 990-994. https://doi.org/10.1038/nature06536

Karesh, W.B., Cook, R.A., Bennett, E.L., Newcomb, J. (2005) Wildlife trade and global disease emergence. Emerging Infectious Diseases, 11(7), 1000-1002. https://dx.doi.org/10.3201/eid1107.050194

Keesing, F., Belden, L.K., Daszak, P., Dobson, A., Harvell, C.D., Holt, R.D., et al. (2010) Impacts of biodiversity on the emergence and transmission of infectious diseases. Nature, 468, 647-652. https://doi.org/10.1038/ nature 09575

Keesing, F., Holt, R.D., Ostfeld, R.S. (2006) Effects of species diversity on disease risk. Ecology Letters, 9, 485-498. https://doi.org/10.1111/j.14610248.2006.00885.x

Kettle, C.J., Koh, L.P. (2014) Global forest fragmentation. CABi International, Wallingford, UK.

Klempa, B. (2009) Hantaviruses and climate change. Clinical Microbiology and Infection, 15(6), 518-523. https://doi.org/10.1111/j.1469-0691.2009.02848.x

Komar, N., Langevin, S., Hinten, S., Nemeth, N., Edwards, E., Hettler, D., et al. (2003) Experimental infection of North American Birds with the New York 1999 strain of West Nile virus. Emerging Infectious Diseases, 9(3), 311-322. https://dx.doi.org/10.3201/ eid0903.020628

Krausmann, F., Erb, K-H., Gingrich, S., Haberl, H., Bondeau, A., Gaube, V., et al. (2013) Global 
human appropriation of net primary production doubled in the 20th century. Proceedings of the National Academy of Sciences, 110, 10324-10329. https://doi.org/10.1073/pnas.1211349110

Lam, T.T., Jia, N., Zhang, Y., Shum, M.H., Jiang, J., Zhu, H., et al. (2020) Identifying SARS-CoV-2 related coronaviruses in Malayan pangolins. Nature, https:// doi.org/10.1038/s41586-020-2169-0

Lee, J.-W., McKibbin, W. (2004) Estimating the Global Economic Costs of SARS. In Knobler, S., Mahmoud, A., Lemon, S., Mack, A., Sivitz, L., Oberholtzer, K., (Eds.), Learning from SARS: Preparing for the next Outbreak. The National Academies Press. pp. 92-109.

Leroy, E., Kumulungui, B., Pourrut, X. Rouquet, P., Hassanin, A., Yaba, P., et al. (2005) Fruit bats as reservoirs of Ebola virus. Nature, 438, 575-576. https:// doi.org/10.1038/438575a

Li, W., Shi, Z., Yu, M., Ren, W., Smith, C., Epstein, J.H., et al. (2005) Bats are natural reservoirs of SARS-like coronaviruses. Science, 310, 676-679. https://doi. org/10.1126/science.1118391

Locey, K.J., Lennon, J.T. (2016) Scaling laws predict global microbial diversity. Proceedings of the National Academy of Sciences, 113, 5970-5975. https://doi. org/10.1073/pnas. 1521291113

LoGiudice, K., Ostfeld, R.S., Schmidt, K.A., Keesing, F. (2003) The ecology of infectious disease: effects of host diversity and community composition on Lyme disease risk. Proceedings of the National Academy of Sciences, 100(2), 567-571. https://doi.org/10.1073/ pnas. 0233733100

LoVerde, P.T. (2019) Schistosomiasis. In: Toledo, R., Fried, B., (Eds.), Digenetic Trematodes. Advances in Experimental Medicine and Biology, vol 1154, Springer, Cham. pp: 45-70. https://doi.org/10.1007/978-3-03018616-6_3

MacDonald, A.J., Mordecai, E.A. (2019) Amazon deforestation drives malaria transmission, and malaria burden reduces forest clearing. Proceedings of the National Academy of Sciences, 116, 22212-22218. https://doi.org/10.1073/pnas.1905315116

McKibbin, W.J., Sidorenko. A.A. (2006) Global macroeconomic consequences of pandemic influenza. Lowy Institute for International Policy, Sydney, Australia.

McMahon, B.J., Morand, S., Gray, J.S. (2018) Ecosystem change and zoonoses in the Anthropocene. Zoonoses and Public Health, 65, 755-765. https://doi. org/10.1111/zph.12489

McMichael, A.J. (2004) Environmental and social influences on emerging infectious diseases: past, present and future. Philosophical Transactions of the Royal
Society B, 359, 1049-1058. https://doi.org/10.1098/ rstb.2004.1480

Merson, M.H., O'Malley, J., Serwadda, D., Apisuk, C. (2008) The history and challenge of HIV prevention. The Lancet, 372, 475-488. https://doi.org/10.1016/ S0140-6736(08)60884-3

Milner-Gulland, E.J., Bennett, E.L., the SCB 2002 Annual Meeting Wild Meat Group. (2003) Wild meat: the bigger picture. Trends in Ecology \& Evolution, 18(7), 351-357. https://doi.org/10.1016/S01695347(03)00123-X

Mills, J.N., Amman, B.R., Glass, G.E. (2010) Ecology of Hantaviruses and their hosts in North America. Vector-Borne and Zoonotic Diseases, 10(6), 563-574. https://doi.org/10.1089/vbz.2009.0018

Morand, S., Jittapalapong, S., Supputamongkol, Y., Abdullah, M.T., Huan, T.B. (2014) Infectious diseases and their outbreaks in Asia- Pacific: biodiversity and its regulation loss matter. PLoS One, 9, e90032. https://doi.org/10.1371/journal.pone.0090032

Morse, S.S. (1995) Factors in the emergence of infectious diseases. Emerging Infectious Diseases, 1, 7-15. https://dx.doi.org/10.3201/eid0101.950102

Morse, S.S., Mazet, J.A.K., Woolhouse, M., Parrish, C.R., Carroll, D., Karesh, W.B., et al. (2012) Prediction and prevention of the next pandemic zoonosis. The Lancet, 380, 1956-1965. https://doi.org/10.1016/S01406736(12)61684-5

Murawiec, S., Tryjanowski, P. (2020) A psychiatrist watches birds during the COVID-19 pandemic: Observations, introspections, interpretations. Psychiatria i Psychologia Kliniczna, 20: 94-97. DOI: $10.15557 /$ PiPK.2020.0012

Murray, K.A., Daszak, P. (2013) Human ecology in pathogenic landscapes: two hypotheses on how land use change drives viral emergence. Current Opinion in Virology, 3, 79-83. https://doi.org/10.1016/j.coviro.2013.01.006

Myers, S.S., Gaffikin, L., Golden, C.D., Ostfeld, R.S., Redford, K.H., Ricketts, T.H., et al. (2013) Human Health impacts of ecosystem alteration. Proceedings of the National Academy of Sciences, 110(47), 1875318760. https://doi.org/10.1073/pnas. 1218656110

Newell, P. (2019) Global Green Politics. Cambridge University Press, Cambridge.

Nijman, V. (2009) An overview of international wildlife trade from Southeast Asia. Biodiversity and Conservation, 19, 1101-1114. https://doi.org/10.1007/ s10531-009-9758-4

Ogden, N.H., Lindsay, L.R. (2016) Effects of climate and climate change on vectors and vector-borne diseases: 
ticks are different. Trends in Parasitology, 32, 646656. https://doi.org/10.1016/j.pt.2016.04.015

Olivero, J., Fa, J.E., Farfán, M.Á., Márquez, A.L., Real, R., Juste, F.J., et al. (2020) Human activities link fruit bat presence to Ebola virus disease outbreaks. Mammal Review, 50(1), 1-10. https://doi.org/10.1111/ mam. 12173

Olivero, J., Fa, J.E., Real, R. Márquez, A.L., Farfán, M.A., Vargas, J.M., et al. (2017) Recent loss of closed forests is associated with Ebola virus disease outbreaks. Scientific Reports, 7, 14291. https://doi.org/10.1038/ s41598-017-14727-9

Ostfeld, R.S., Holt, R.D. (2004) Are predators good for your health? Evaluating evidence for top-down regulation of zoonotic disease reservoirs. Frontiers in Ecology and the Environment, 2(1), 13-20. https:// doi.org/10.1890/1540-9295(2004)002[0013:APGFY$\mathrm{H}] 2.0 . \mathrm{CO} ; 2$

Ostfeld, R.S., Keesing, F. (2000) Biodiversity and disease risk: the case of Lyme disease. Conservation Biology, 14(3), 722-728. https://doi.org/10.1046/j.15231739.2000.99014.x

Ostfeld, R.S., Keesing, F. (2020) Species that can make us ill thrive in human habitats. Nature, 584: 346-347. doi: 10.1038/d41586-020-02189-5

Park, C.Y., Villafuerte, J., Abiad, A., Narayanan, B., Banzon, E., Samson, J., et al. (2020) An updated assessment of the economic impact of COVID-19. ADB Briefs, 133, 1-16. http://dx.doi.org/10.22617/ BRF200144-2

Pasqualetti, F., Zhao, S., Favaretto, C., Zampieri, S. (2020) Fragility Limits Performance in Complex Networks. Scientific Reports, 10, 1774. https://doi.org/10.1038/ s41598-020-58440-6

Patz, J.A., Campbell-Lendrum, D., Holloway, T., Foley, J.A. (2005) Impact of regional climate change on human health. Nature, 438, 310-317. https://doi. org/10.1038/nature04188

Patz, J.A., Daszak, P., Tabor, G.M., Aguirre, A.A., Pearl, M., Epstein, J., et al. (2004) Unhealthy landscapes: policy recommendations on land use change and infectious disease emergence. Environmental Health Perspectives, 112, 1092-1098. https://doi. org/10.1289/ehp.6877

Patz, J.A., Epstein, P.R., Burke, T.A., Balbus, J.M. (1996) Global climate change and emerging infectious diseases. Journal of the American Medical Association, 275(3), 217-223. https://doi.org/10.1001/ jama.1996.03530270057032
Pavlin, B.I., Schloegel, L.M., Daszak, P. (2009) Risk of importing zoonotic diseases through wildlife trade, United States. Emerging Infectious Diseases, 15(1), 1721-1726. https://dx.doi.org/10.3201/ eid1511.090467

Pearce-Duvet, J.M.C. (2006) The origin of human pathogens: evaluating the role of agriculture and domestic animals in the evolution of human disease. Biological Review, 81, 369-382. https://doi.org/10.1017/ S1464793106007020

Peeters, M., Courgnaud, V., Abela, B., Auzel, P., Pourrut, X., Bibollet-Ruche, F., et al. (2002) Risk to human health from plethora of simian immunodeficiency viruses in primate bushmeat. Emerging Infectious Diseases, 8(5), 451-457. https://dx.doi.org/10.3201/ eid0805.010522

Petersen, L.R., Brault, A.C., Nasci, R.S. (2013) West Nile Virus: Review of the literature. Journal of the American Medical Association, 310(3), 308-315. https:// doi.org/10.1001/jama.2013.8042

Pike, J., Bogich, T., Elwood, S., Finnoff, D.C., Daszak, P. (2014) Economic optimization of a global strategy to address the pandemic threat. Proceedings of the National Academy of Sciences, 111(52), 18519-18523. https://doi.org/10.1073/pnas.1412661112

Pimentel, D., McNair, S., Janecka, J., Wightman, J., Simmonds, C., O’Connel, C., et al. (2001) Economic and environmental threats of alien plant, animal, and microbe invasions. Agriculture, Ecosystems \& Environment, 84(1), 1-20. https://doi.org/10.1016/S01678809(00)00178-X

Pimm, S.L., Jenkins, C.N., Abell, R., Brooks, T.M., Gittleman, J.L., Joppa, L.N., et al. (2014) The biodiversity of species and their rates of extinction, distribution, and protection. Science, 344, 1246752. https://doi. org/10.1126/science. 1246752

Plowright, R.K., Parrish, C.R., McCallum, H., Hudson, P.J., Ko, A.I., Graham, A.L., Lloyd-Smith, J.O. (2017) Pathways to zoonotic spillover. Nature Reviews Microbiology, 15, 502-510. https://doi.org/10.1038/nrmicro.2017.45

Plowright, R.K., Sokolow, S.H., Gorman, M.E., Daszak, P., Foley, J.E. (2008) Causal inference in disease ecology: investigating ecological drivers of disease emergence. Frontiers in Ecology and the Environment, 6, 420-429. https://doi.org/10.1890/070086

Pongsiri, M.J., Roman, J., Ezenwa, V.O., Goldberg, T.L., Koren, H.S., Newbold, S.C., et al. (2009) Biodiversity loss affects global disease ecology. BioScience, 59(11), 945-954. https://doi.org/10.1525/ bio.2009.59.11.6 
Reed, K.D., Melski, J.W., Graham, M.B., Regnery, R.L., Sotir, M.J., Wegner, M.V., et al. (2004) The detection of monkeypox in humans in the Western Hemisphere. The New England Journal of Medicine, 350, 342-350. https://doi.org/10.1056/nejmoa032299

Ripple, W.J., Wolf, C., Newsome, T.M., Barnard, P., Moomaw, W.R. (2020) World Scientists' Warning of a Climate Emergency. BioScience, 70, 8-12. https:// doi.org/10.1093/biosci/biz088

Richardson, K.S., Kuenzi, A., Douglass, R.J., Hart, J., Carver, S. (2013) Human exposure to particulate matter potentially contaminated with Sin Nombre Virus. EcoHealth, 10(2), 159-165. https://doi.org/10.1007/ s10393-013-0830-X

Rohr, J.R., Civitello, D.J., Crumrine, P.W., Halstead, N.T., Miller, A.D., Schotthoefer, A.M., et al. (2015) Predator diversity, intraguild predation, and indirect effects drive parasite transmission. Proceedings of the National Academy of Sciences, 112(10), 3008-3013. https://doi.org/10.1073/pnas.1415971112

Rulli, M.C., Santini, M., Hayman, D.T.S., D’Odorico, P. (2017) The nexus between forest fragmentation in Africa and Ebola virus disease outbreaks. Scientific Reports, 7, 41613. https://doi.org/10.1038/srep41613

Samways, M. (1999) Translocating fauna to foreign lands: Here comes the Homogenocene. Journal of Insect Conservation, 3, 65-66.

Scheffers, B.R., Oliveira, B.F., Lamb, I., Edwards, D.P. (2019) Global wildlife trade across the tree of life. Science, 366, 71-76. https://doi.org/10.1126/science. aav5327

Schmidt, J.K., Ostfeld, R.S. (2001) Biodiversity and the dilution effect in disease ecology. Ecology, 82(3), 609-619. https://doi.org/10.1890/0012-9658(2001)08 2[0609:BATDEI]2.0.CO;2

Sharp, P.M., Hahn, B.H. (2011) Origins of HIV and the AIDS pandemic. Cold Spring Harbor Perspectives in Medicine, 1(1), a006841. https://doi.org/10.1101/cshperspect.a006841

Sheahan, T.P., Frieman, M.B. (2020) The continued epidemic threat of SARS-CoV-2 and implications for the future of global public health. Current Opinion in Virology, https://doi.org/10.1016/j.coviro.2020.05.010

Sirotkin, K., Sirotkin, D. (2020) Might SARS-CoV-2 Have Arisen via Serial Passage through an Animal Host or Cell Culture? BioEssays, 42, 2000091. https://doi. org/10.1002/bies.202000091

Skórka, P., Grzywacz, B., Moroń, D., Lenda, M. (2020) The macroecology of the COVID-19 pandemic in the
Anthropocene. PLoS ONE 15(7): e0236856. https:// doi.org/10.1371/journal.pone.0236856

Soga, M., Evans, M.J., Tsuchiya, K., Fukano, Y. (2020) A room with a green view: the importance of nearby nature for mental health during the COVID-19 pandemic. Ecological Applications, e2248. https://doi. org/10.1002/eap.2248

Stauffer, J.R., Madsen, H., McKaye, K., Konings, A., Bloch, P., Ferreri, C.P., et al. (2006) Schistosomiasis in Lake Malawi: relationship of fish and intermediate host density to prevalence of human infection. EcoHealth, 3, 22-27. https://doi.org/10.1007/s10393-0050007-3

Steffen, W., Crutzen, P.J. McNeill, J.R. (2007) The Anthropocene: Are Humans Now Overwhelming the Great Forces of Nature? Ambio, 36, 614-621. https://doi. org/10.1579/0044-7447(2007)36[614:TAAHNO]2.0. $\mathrm{CO} ; 2$

Sultan, B., Labadi, K., Guégan, J.-F., Janicot, S. (2005) Climate drives the meningitis epidemics onset in West Africa. PLoS Medicine, 2(1), e6. https://doi. org/10.1371/journal.pmed.0020006

Swaddle, J.P., Calos, S.E. (2008) Increased avian diversity is associated with lower incidence of human West Nile infection: observation of the dilution effect. PLoS ONE, 3, e2488. https://doi.org/10.1371/journal. pone. 0002488

Swift, L., Hunter, P.R., Lees, A.C., Bell, D.J. (2007) Wildlife trade and the emergence of infectious diseases. EcoHealth, 4, 25-30. https://doi.org/10.1007/s10393006-0076-y

Taylor, L.H., Latham, S.M., Woolhouse, E.J. (2001) Risk factors for human disease emergence. Philosophical Transactions of the Royal Society B, 356, 983-989. https://doi.org/10.1098/rstb.2001.0888

Toledo, L.F., Asmüssen, M.V., Rodríguez, J.P. (2012) Track illegal trade in wildlife. Nature, 483, 36. https:// doi.org/10.1038/483036e

Vittor, A.Y., Pan, W., Gilman, R.H., Tielsch, J., Glass, G., Shields, T., et al. (2009) Linking deforestation to malaria in the Amazon: characterization of the breeding habitat of the principal malaria vector, Anopheles darlingi. American Journal of Tropical Medicine and Hygiene, 81(1), 5-12.

Wilcox, B.A., Ellis, B. (2006) Forests and emerging infectious diseases of humans. Unasylva, 224(57), 11-18.

Wolfe, N.D., Dunavan, C.P., Diamond, J. (2007) Origins of major human infectious diseases. Nature, 447, 279283. https://doi.org/10.1038/nature05775 
Wood, C.L., Lafferty, K.D. (2013) Biodiversity and disease: a synthesis of ecological perspectives on Lyme disease transmission. Trends in Ecology \& Evolution, 28(4), 239-247. https://doi.org/10.1016/j. tree.2012.10.011

World Bank (2012) People, pathogens and our planet. Volume 2: The economics of one Health. Report No. 69145-GLB.

World Health Organization (2020) Ebola Virus Disease. https://www.who.int/news-room/fact-sheets/detail/ ebola-virus-disease
Wu, F., Zhao, S., Yu, B., Chen, Y., Wang, W., Song, Z., et al. (2020) A new coronavirus associated with human respiratory disease in China. Nature, 579, 265-269. https://doi.org/10.1038/s41586-020-2008-3

Zhou, P., Yang, X.L., Wang, X., Hu, B., Zhang, L., Zhang, W., et al. (2020) A pneumonia outbreak associated with a new coronavirus of probable bat origin. Nature, 579, 270-273. https://doi.org/10.1038/s41586020-2012-7 